\title{
APLIKASI MODEL E-MARKETPLACE DALAM E-AGRIBUSINESS
}

\author{
Hilmi Arija Fachriyan, I Putu Eka Wijaya \\ Program Studi Agribisnis Fakultas Pertanian \\ Universitas Wahid Hasyim Semarang \\ hilmi.arija16@gmail.com
}

\begin{abstract}
Economic activity is currently entering an era called the era of digital economy. Digital economy involves the process of e-business or e-commerce that utilizes the internet network. The rapid growth of internet users in Indonesia has affected the agribusiness sector to adopt e-commerce called e-agribusiness.In line with the development of the internet, a new understanding of electronic marketing paradigm in e-agribusiness in the form of e-marketplace. Some agribusiness emarketplace sites have been born in Indonesia such as "agromaret.com", "kecipir.com", "limakilo.id", and "agribisnispedia.com". These five agribusiness e-marketplaces each have their own characteristics, advantages and disadvantages. Basically, the success of an e-marketplace depends heavily on the level of involvement of the participating participants. The lack of e-marketplace reliability is often criticized as one of the key factors that reduce the confidence of sellers or buyers to participate. The process of maturing the e-marketplace is needed to influence the user's perception of the quality of the technical service, the quality of the content service and the quality of customer service. Therefore, there is pressure on the provider side to improve the quality of its services and offer something unique above industry standards to achieve a competitive advantage over other agribusiness e-marketplaces.
\end{abstract}

Keywords:e-commerce, e-agribusiness, e-marketplace.

\section{PENDAHULUAN}

Kegiatan ekonomi saat ini tengah memasuki suatu era yang dinamakan era digital economy. Pertumbuhan, integrasi, dan kecanggihan teknologi informasi dan komunikasi menyebabkan perubahan mendasar dalam kegiatan ekonomi. Kapasitas internet untuk mengakses, mengatur dan mengkomunikasikan informasi dengan cara yang lebih efisien telah membawa formula baru dalam hubungan antara produsen dan konsumen. Digital economy melibatkan proses e-business (bisnis di lingkungan elektronik) yang mencakup seluruh rantai nilai seperti pembelian, manajemen rantai pasokan, pemrosesan order, penanganan pelayanan pelanggan, dan kerjasama dengan mitra bisnis. Dalam dunia sistem informasi, $e$ business biasa disebut dengan istilah $e$-commerce.

E-commerce merupakan model bisnis baru di lingkungan elektronik yang memanfaatkan jaringan internet. Salah satu faktor yang berkontribusi terhadap adopsi e-commerce adalah penetrasi pengguna internet (Su Chun et al., 2007). Menurut data APJII (2016), jumlah pengguna internet di Indonesia mencapai 88 
juta orang hingga akhir tahun 2014. Apabila dibandingkan dengan jumlah penduduk Indonesia yang berjumlah sekitar 253 juta, maka penetrasi pengguna internet di Indonesia mencapai 34,9\%. Nilai ini mendudukkan Indonesia di peringkat ke- 6 terbesar di dunia dalam hal jumlah pengguna internet. Lembaga riset pasar e-Marketer bahkan memproyeksikan netter Indonesia bakal mencapai 112 juta orang pada tahun 2017, mengalahkan Jepang di peringkat ke-5 yang pertumbuhan jumlah pengguna internetnya lebih lamban (Kominfo, 2016).

Pertumbuhan pesat pengguna internet di Indonesia telah mempengaruhi berbagai sektor industri untuk mengambil keuntungan dari "revolusi informasi" yang diberikan oleh internet, termasuk sektor agribisnis. Beberapa ahli mengatakan bahwa internet memiliki kemampuan untuk meningkatkan kinerja pada sektor agribisnis, antara lain melalui penghematan waktu karena tersedia informasi (Rolfe et al., 2003), penciptaan pasar tambahan input dan output (Gabriele, 2004), dan meningkatkan daya saing (Courtright, 2004; Smith et al., 2004). Sementara Fruhling dan Digman (2000) menambahkan bahwa sektor agribisnis berpotensi untuk diterapkan e-commerce yang mengacu pada penggunaan internet untuk pasar, jual beli barang dan jasa, pertukaran informasi, serta menciptakan dan memelihara hubungan berbasis web antar pengguna. Aplikasi e-commerce dalam sektor agribisnis disebut dengan e-agribusiness (Soekartawi, 2007). E-agribusiness menawarkan peluang besar bagi produsen dan pengecer, sekaligus menuntut kajian mendalam mengenai strategi pemasaran dan pengetahuan konsumen (Goldsmith dan Bridges, 2000; Jones dan Vijayasarathy, 1998). Aplikasi yang berhubungan dengan e-agribusiness dapat dikategorikan dari sudut pandang petani menurut faktor produksi, layanan, dan output (Cloete dan Doens, 2008; Manouselis et al., 2009).

Sejalan dengan berkembangnya internet, muncul pemahaman baru mengenai paradigma e-commerce berupa konsep pemasaran modern yang berorientasi pasar atau revolusi pemasaran yang disebut $e$-marketplace (Bakos et al., 1999; Chaffey et al., 2000; Arnott dan Bridgewater, 2002; Eid dan Trueman, 2002). Konsep e-marketplace secara konvensional bisa dianalogikan seperti pasar tradisional dimana banyak orang berkumpul untuk melakukan transaksi jual beli, bedanya penjual dan pembeli bertemu secara virtual. Kalangan ekonom memberikan gagasan bahwa transparansi dan efisiensi yang lebih besar terdapat pada pasar digital (e-marketplace). Karakteristik transparansi yang paling diharapkan dalam hal menyertakan harga, kualitas, dan ketersediaan produk (Smith et al., 2000). Sementara Bakos (1997) menunjukkan bahwa adanya pengurangan biaya pada pasar digital akan mampu meningkatkan efisiensi dan persaingan harga antara penjual. Beberapa situs e-marketplace agribisnis juga telah muncul di Indonesia seperti "agromaret.com", "kecipir.com", "limakilo.id", dan "agribisnispedia.com". Beberapa situs ini menyediakan info pasar sekaligus berperan sebagai pasar elektronik(e-marketplace) yang berfokus pada sektor agribisnis.

Berdasarkan studi-studi sebelumnya, dapat dikatakan bahwa e-marketplace merupakan konsep pemasaran baru di lingkungan elektronik yang berpotensi untuk menunjang e-agribusiness. Namun, berbagai tantangan baru di lingkungan elektronik muncul seiring dengan lahirnya berbagai e-marketplace di Indonesia 
yang mulai tumbuh secara signifikan selama beberapa tahun terakhir. Tren ini kemudian mendorong adanya kebutuhan untuk meninjau kembali model bisnis yang ada. Makalah ini mencoba untuk membahas sampai sejauh mana perkembangan $e$-marketplace agribisnis di Indonesia.

\section{E-MARKETPLACE AGRIBISNIS DI INDONESIA}

Berdasarkan waktu berdirinya, "Agromaret" merupakan e-marketplace agribisnis yang berdiri pertama kali di Indonesia dan telah beroperasi sejak tahun 2009. Sekitar empat tahun berselang, tepatnya bulan April 2013 berdiri $e$ marketplace bernama "LOFMart" yang kemudian melakukan rebranding menjadi "Kecipir" awal tahun 2016. Tren ini juga diikuti oleh "Limakilo" yang berdiri pada bulan November 2015, dan terakhir "Agribisnispedia" pada pertengahan tahun 2016.

\section{Agromaret.com}

Di "Agromaret", member dapat memposting atau memasang iklan dalam tiga (3) kategori utama, yaitu"Penjualan", "Permintaan", dan "Kerjasama". "Agromaret" juga menampilkan informasi "Terbaru" untuk setiap kategori yang baru diposting pada halaman awal website. Untuk kategori penjualan, produk agribisnis yang dijual dikelompokkan seperti yang disajikan pada Tabel 1., sedangkan untuk kategori permintaan dan kerjasama dikelompokkan dalam empat (4) kategori produk, yaitu“pertanian", "peternakan", "perikanan", dan "lain-lain". Halaman awal "agromaret.com" juga menampilkan jumlah agripreneur atau member di "Agromaret" yang telah mencapai sekitar 119 ribu orang sampai dengan Juli 2017. Namun apabila dicek lebih lanjut, ternyata juga ditemukan pengguna yang sudah tidak aktif, serta beberapa akun dari orang yang sama.

Proses transaksi di "Agromaret" sebelumnya dilakukan secara independen oleh kedua pihak (penjual dan pembeli) melalui informasi kontak yang tersedia di profil pengguna seperti nomor telepon atau email. Namun akibat sering terjadi beberapa masalah seperti kasus penipuan atau transaksi kolusif oleh pihak-pihak yang tidak bertanggung jawab, pada 19 Juli 2017 "Agromaret" meluncurkan fitur baru berupa "rekening bersama" dengan tujuan agar proses transaksi menjadi lebih aman. Sejak adanya fitur baru, mekanisme transaksi di "Agromaret" telah berubah menjadi beberapa tahapan, yaitu:

1) Pengajuan pesanan

Pembeli memilih produk yang ingin dibeli, kemudian mengisi form detail pesanan yang akan diajukan kepada penjual. Setelah produk yang diposting penjual dipilih oleh pembeli, selanjutnya icon pemberitahuan transaksi milik penjual akan memberitahukan adanya transaksi baru.

2) Negosiasi

Pada tahap ini, pembeli dan penjual bernegosiasi terkait harga, shipping, dan lain-lain. Selanjutnya tagihan akan dibuat sesuai dengan hasil kesepakatan negoisasi.

3) Pembayaran 
Tagihan yang telah disepakati akan diteruskan oleh sistem "Agromaret" ke email penjual dan pembeli. Pembeli diminta untuk melakukan pembayaran ke salah satu rekening yang disediakan oleh "Agromaret".

4) Konfirmasi pembayaran

Setelah melakukan pembayaran, pembeli diminta untuk mengisi form konfirmasi pembayaran, sehingga status transaksi "Dibayar" menyala. Status "Dibayar" berarti bahwa dana yang dibayarkan pembeli sudah masuk ke rekening "Agromaret".

5) Persiapan barang

Status pembayaran berhasil, selanjutnya penjual melakukan packing barang sesuai pesanan pembeli serta mendownload "form penerimaan dan pengembalian barang".

6) Dikirim

Penjual mengirim barang dengan menyertakan "form penerimaan dan pengembalian barang" yang sudah diprint. Jika barang sudah dikirim, penjual diminta untuk melakukan konfirmasi pengiriman yakni dengan melengkapi form yang berisi tanggal pengiriman dan estimasi barang sampai.

7) Diterima

a. Pembeli menerima barang dan menandatangani "form penerimaan barang" dari kurir. Selanjutnya pembeli melakukan konfirmasi terima barang, mengisi ulasan transaksi, dan memberi rating kepada penjual (bintang 1-5) berdasarkan kesan pembeli kepada penjual selama bertransaksi.

b. Penjual memastikan kurirnya membawa kembali form penerimaan barang yang sudah ditandatangani pembeli untuk melakukan upload bukti penerimaan barang.

8) Selesai

Transaksi telah berhasil dan penjual dapat melihat ulasan beserta rating yang diberikan oleh pembeli. Dana yang dibayarkan pembeli ke rekening "Agromaret" selanjutnya diteruskan ke "Dompet Agromaret" milik penjual. Penjual sewaktu-waktu dapat mencairkan dana tersebut melalui menu dompet pada profil penjual.

\section{Kecipir.com}

Awalnya "Kecipir"hanya menjual sayuran organik. Namun belakangan ini "Kecipir" sudah menyediakan buah-buahan organik seperti alpukat, pisang ambon, pepaya, dan lainnya. "Kecipir" juga melengkapi produk jualannya dengan telur ayam negeri, beras putih, ayam probiotik, tempe organik, dan lainnya. Sementara ini sudah tercatat 120 produk yang tersedia. Untuk bisa bertransaksi di "Kecipir", konsumen diwajibkan mendaftarkan diri terlebih dahulu sebagai anggota/member dari salah seorang agen "Kecipir". Pemilihan lokasi agen diperlukan untuk menentukan "host" dimana konsumen bisa mengambil produk yang sudah dipesan. Keuntungan sistem keanggotaan ini adalah para anggota dapat bertemu komunitas sesama konsumen produk organik dan diharapkan sesama anggota dapat mengembangkan ide-ide mengenai cara hidup yang lebih 
sehat dengan produk organik. Saat ini "Kecipir" baru menjangkau wilayah "Jabodetabek" saja yaitu Tangerang Selatan (32 agen), Kota Tangerang (10 agen), Jakarta Utara (14 agen), Jakarta Timur (18 agen), Jakarta Selatan (31 agen), Jakarta Pusat (8 agen), Jakarta Barat (8 agen), Depok (20 agen), Cibubur (5 agen), Bogor (17 agen), dan Bekasi (11 agen).

Produk yang dijual di "Kecipir" dibagi dalam tiga (3) tingkatan, yaitu Grade AA (hasil alam), Grade A (organik bersertifikat), dan Grade B (organik belum bersertifikat). Untuk pemesanan, "Kecipir" memiliki "jadwal pengantaran" dan "jadwal order"sebagai batas waktu pemesanan. Proses pemesanan di "Kecipir" cukup sederhana. Pertama, member memilih produk yang ingin dipesan lalu klik "Add to Chart" untuk ditambahkan ke keranjang belanja online. Selanjutnya tentukan berapa jumlah pesanan berdasarkan sisa stok produk dan secara otomatis sistem akan menghitung total harga yang harus dibayar. Terakhir, klik "Checkout" untuk melakukan pembayaran. Setelah "Checkout", member diwajibkan melakukan pembayaran dalam jangka waktu 24 jam. Apabila melewati jangka waktu tersebut, pesanan otomatis akan dibatalkan. Setelah melakukan pembayaran, pesanan tidak dapat diubah/dibatalkan. Pesanan akan disiapkan oleh petani dan didistribusikan ke agen pada waktu yang telah ditentukan. Pembayaran di "Kecipir" menggunakan metode COD (Cash on Delivery), Credit Card, transfer bank, dan Greencash (deposit saldo di “Kecipir”).

Tabel 1. Kategori Penjualan di Agromaret

\begin{tabular}{llll}
\hline Pertanian & Peternakan & Perikanan & Lain-lain \\
\hline Hasil Tani & Ternak & Air Tawar & Hasil Bumi \\
Hasil Kebun & Hasil Ternak & Air Laut & Lahan \\
Hasil Hutan & Alat Mesin Peternakan & Olahan Air Tawar & Jasa Angkutan \\
Olahan Pertanian & Pakan, Obat, Vitamin & Olahan Air Laut & Lainnya \\
Olahan Perkebunan & Lainnya & Alat Mesin Perikanan & \\
Olahan Kehutanan & & Bibit Ikan & \\
Alat Mesin Pertanian & & Ikan Hias & \\
Pupuk, Pestisida, Obat & & Pakan, Obat, Vitamin & \\
Bibit Tanaman & & Lainnya & \\
Buah-buahan & & \\
Sayuran & & \\
Tanaman Hias & & & \\
Lainnya & & & \\
\hline
\end{tabular}

Sumber : agromaret.com

\section{Limakilo.id}

"Limakilo" hadir sebagai e-marketplace agribisnis yang memiliki harapan besar supaya masyarakat bisa membeli komoditas pangan langsung dari petani. "Limakilo" berharap dapat mengefisienkan pola distribusi produk pertanian karena petani dan pembeli bisa dipertemukan langsung melalui layanan ini. "Limakilo" menyediakan layanan bagi penggunanya dalam empat (4) pilihan menu utama, yaitu "Petani Mitra", "Belanja", "Grosir", dan "Pasar Petani".

Menu "Petani Mitra" menawarkan kesempatan kepada petani di seluruh wilayah Indonesia yang ingin menyuplai produk berdasarkan daftar komoditas yang disediakan "Limakilo" seperti bawang merah, bawang putih, bawang bombay, tomat sayur, cabai, dan kentang. Untuk menjadi "Petani Mitra", petani 
tinggal memilih komoditas produk yang ingin disuplai dan mengisi data pada "Formulir Suplai". Setelah mengisi dan mengirimkan data, calon petani mitra akan dihubungi oleh tim dari "Limakilo". Status hubungan antara "Petani Mitra" dengan "Limakilo" adalah "jual-putus". Artinya petani tidak terikat apapun dengan "Limakilo" setelah produk dibayar oleh "Limakilo".

Menu "Belanja" menyajikan informasi tentang "Produk pilihan" dan "Komoditas yang sedang panen hari ini". Daftar produk yang dijual adalah"hasil panen petani Limakilo" dan "hasil panen pemerintah". Produk dijual dalam satuan "pack" dengan paket minimal pembelian yang berbeda-beda. Masing-masing produk dicantumkan historis penjualan sebelumnya beserta sisa persediaan/stok. Mekanisme pembelian pada menu ini relatif mudah dan sederhana. Pembeli tinggal memilih produk yang ingin dibeli beserta kuantitasnya lalu klik "Beli". Secara otomatis produk yang dipilih akan ditambahkan dalam keranjang belanja online. Jika sudah selesai memilih produk, pembeli tinggal klik "Checkout" kemudian sistem akan menghitung total harga yang harus dibayar beserta ongkos kirim menurut lokasi alamat tujuan. Terakhir, pembeli membayar total tagihan belanja ke rekening yang disediakan"Limakilo". Order yang tidak dibayar setelah lebih dari 24 jam terhitung dari order diterima akan dianggap batal. Saat ini "Limakilo" hanya melayani orderan untuk daerah Jakarta, Depok, Tangerang, Bekasi, dan Bandung.

Pada menu "Grosir", pemilik usaha makanan atau katering diberikan penawaran belanja dengan harga grosir oleh "Limakilo". Tiga keuntungan yang dijanjikan "Limakilo" bagi pelanggan grosir antara lain pelayanan yang cepat, dapat memilih jatuh tempo pembayaran, dan jaminan kualitas. Untuk bisa berlangganan secara grosir, calon pelanggan diminta terlebih dahulu untuk mendaftarkan usahanya dengan mengisi data pada form daftar usaha seperti nama usaha, nama komoditi, jumlah kebutuhan, nomor telepon, dan email. Setelah mendaftar, selanjutnya calon pelanggan akan dihubungi oleh sales "Limakilo" untuk panduan pembelanjaan grosir.

Di menu "Pasar Petani", pengguna dapat memposting iklan dalam dua (2) pilihan "ingin jual" atau "ingin beli". Kategori "Jual" menampilkan nama komoditas, harga, dan ketersediaan. Sementara untuk kategori "Beli" menampilkan nama komoditas, harga, dan kebutuhan. Masing-masing produk baik untuk kategori "Jual" maupun "Beli" memberikan deskripsi produk mulai dari ukuran, warna, jenis/tipe, dan grade. Mekanisme transaksi pada menu ini dilakukan secara independen antara penjual dan pembeli dengan melakukan hubungan langsung melalui informasi nomor telepon atauemail yang dicantumkan dalam profil penjualan/pembelian produk.

\section{Agribisnispedia.com}

"Agribisnispedia"merupakan e-marketplace yang menghubungkan pelaku usaha agribisnis dengan konsumen secara online. Siapapun dapat membuka toko, berjualan, dan mengembangkan bisnis di "agribisnispedia.com". Produk yang dapat dipasarkan di "Agribisnispedia" adalah semua produk agribisnis yang meliputi pertanian, peternakan, perikanan, dan kehutanan. Halaman utama "agribisnispedia.com" menampilkan kategori produk beserta informasi "Hot List", 
"Produk Terbaru", dan "Iklan". Kategori produk yang dipasarkan di "Agribisnispedia" dibagi dalam 24 kategori yang spesifik (Tabel 2). Namun di antara ke-24 kategori tersebut, ada empat (4) kategori yang masih kosong atau belum ada produk yang dijual. Empat kategori tersebut yaitu "Perikanan Laut, Seafood", "Produk Organik", "Agrowisata", dan "Produk Inovatif Unggulan".

Pembelian produk di "Agribisnispedia" dilakukan dengan cara menghubungi langsung penjual melalui informasi kontak yang tercantum pada profil penjual seperti nomor telepon, email, dan alamat. Lalu untuk alasan keamanan, "Agribisnispedia" juga memfasilitasi proses transaksi melalui rekening bersama. Namun pembayaran melalui rekening bersama ini belum by system atau masih dilakukan secara manual dengan menghubungi pihak "Agribisnispedia". Dalam upaya mengembangkan layanannya, "Agribisnispedia" menawarkan kerjasama "investorship" melalui kolaborasi dengan investor. "Agribisnispedia" juga menawarkan kerjasama lainnya berupa "Pasang Iklan" yang akan ditempatkan pada space yang disediakan dan ditampilkan pada halaman utama.

Tabel 2. Kategori Penjualan di Agribisnispedia

\begin{tabular}{cccc}
\hline Peralatan, Perlengkapan & Agroindustri & Perkebunan & Buah-buahan \\
\hline $\begin{array}{c}\text { Jamu, Herbal, } \\
\text { Tanaman obat }\end{array}$ & Makanan dan Minuman & $\begin{array}{c}\text { Pupuk, Obat, } \\
\text { Media Tanam }\end{array}$ & Perikanan \\
\hline Kehutanan & Peternakan & $\begin{array}{c}\text { Kerajinan dan } \\
\text { Agri Kreatif }\end{array}$ & $\begin{array}{c}\text { Buah dan } \\
\text { Tanaman Hias }\end{array}$ \\
\hline Buku dan Majalah & Bumbu dan Rempah & $\begin{array}{c}\text { Benih dan Bibit } \\
\text { Tanaman }\end{array}$ & Sayuran \\
\hline Jamur & Umbi-umbian & $\begin{array}{c}\text { Beras, Biji-bijian, } \\
\text { Kacang }\end{array}$ & Ikan Hias, Hewan Hobi \\
\hline $\begin{array}{c}\text { Perikanan Laut, } \\
\text { Seafood }\end{array}$ & Produk Organik & Agrowisata & $\begin{array}{c}\text { Produk Inovatif } \\
\text { Unggulan }\end{array}$ \\
\hline
\end{tabular}

Sumber : agribisnispedia.com

\section{HASIL DAN PEMBAHASAN}

Kelima e-marketplace agribisnis yang telah dibahas sebelumnya memiliki keunggulan atau ciri khas masing-masing. Misalnya "agromaret.com" dengan banyak agripreneur yang telah bergabung, "kecipir.com" yang menjual khusus produk organik melalui sistem agen, "limakilo.id" yang bekerjasama dengan pemerintah dalam penjualan produk, serta "agribisnispedia.com" yang mengkategorikan produk penjualan dengan lebih spesifik. Namun untuk mengetahui kematangan suatu e-marketplace, diperlukan pendekatan yang lebih konsumen sentris terutama dalam hal kegunaan komponen website dan pelayanan.

Komponen website dan layanan pelanggan terkait dengan kualitas pelayanan umum di lingkungan e-commerce. Layanan pelanggan merupakan komponen penting dalam e-commerce (Sullivan dan Kent, 2001), dan komponen website adalah sarana utama dalam memberikan kualitas layanan (Zeithamlet al., 2002). Kualitas layanan dapat disampaikan dalam dua cara, yakni teknologi otomatisasi dan keterlibatan manusia (Nasret al., 2012). Kualitas website menilai aspek teknologi otomatisasi kualitas layanan yang menekankan tampilan dan konten. Sebaliknya, kualitas layanan pelanggan menyangkut aspek keterlibatan kualitas pelayanan manusia dalam hal respon dan empati. 
Komponen spesifik website seperti tampilan dan fitur pada e-marketplace bisa mempengaruhi penilaian dari perspektif pengguna perihal kemudahan penggunaan, kualitas konten, dan kebutuhan individu pengguna (Agarwal dan Venkatesh, 2002). Sebagai contoh, untuk e-marketplace dengan banyak penjual seperti "Agromaret" dan "Agribisnispedia", layanan konten berupa "chat online" pada website sangat diperlukan oleh konsumen. "Chat online" sangat dibutuhkan dalam proses belanja terutama bagi konsumen yang ingin memastikan dulu ketersediaan produk sebelum bertransaksi. Fitur seperti "Hubungi Penjual" yang dimiliki "Agromaret" menjadi penting karena dapat digunakan oleh konsumen untuk menanyakannya langsung kepada penjual. Sayangnya fitur seperti ini belum ada pada "Agribisnispedia", sehingga konsumen mesti menghubungi penjual melalui nomor telepon bila ingin bertanya. Untuk "Kecipir" dan "Limakilo" yang menjalankan proses penjualan sendiri, konsumen bisa langsung bertanya melalui layanan bantuan "chat admin online". Sementara "Agromaret" yang sudah memiliki fitur "Hubungi Penjual" juga menambahkan layanan "chat admin online" untuk meningkatkan kualitas konten layanan.

Selain meningkatkan layanan konten, e-marketplace juga harus mempertimbangkan komponen teknis website seperti keamanan, interaktivitas, kecepatan loading halaman, dan layanan pelanggan (Aladwani dan Palvia, 2002). Keamanan transaksi merupakan salah satu faktor yang paling diperhatikan oleh pembeli, terutama pada e-marketplace dengan banyak penjual seperti "Agromaret" dan "Agribisnispedia". Beberapa kasus penipuan oleh penjual di "Agromaret" yang sebelumnya pernah terjadi, disebabkan karena tidak adanya sistem teknis untuk mengatur proses transaksi. Masalah ini kemudian direspon oleh "Agromaret" dengan menambahkan fitur "rekening bersama" pada sistemnya. Prinsip kerja "rekening bersama" adalah menahan dulu dana yang dibayarkan pembeli di rekening "Agromaret" sementara penjual mengirim barang pesanan pembeli, setelah barang diterima oleh pembeli baru kemudian dana akan diteruskan kepada penjual. Fitur ini juga memiliki sistem untuk merekam status transaksi (dibayar/dikirim/diterima) yang dapat dilihat dan dicek di website"Agromaret". Sementara itu, "Agribisnispedia" juga melayani fasilitas rekening bersama, tetapi fasilitas yang diberikan bukan bagian dari komponen teknis di sistemnya. Fitur "rekening bersama" telah menjadi solusi umum untuk mengatur proses transaksi yang aman bagi pembeli. Beberapa $e$-marketplace besar di Indonesia yang memiliki banyak sekali penjual seperti "Tokopedia" dan "Bukalapak" juga menggunakan fitur ini.

Selanjutnya untuk "Kecipir" dan "Limakilo" yang menjalankan proses penjualannya sendiri harus mampu memberikan pembeli online jaminan keamanan dan privasi, serta meningkatkan layanan pelanggan untuk membangun kepercayaan pelanggan. Dibandingkan dengan layanan konten, layanan pelanggan membutuhkan keterlibatan manusia secara langsung. Layanan kepada pelanggan harus menunjukkan kepedulian dan perhatian secara khusus. Bukan hanya menanggapi permintaan pelanggan dengan segera demi mempertahankan pelanggan, namun terutama ketika mereka mengalami masalah berat hingga menyebabkan kegagalan transaksi danmerugikan pelanggan. Sementara pada "Agromaret" dan "Agribisnispedia",resiko dan kesalahan dalam transaksi bisa 
saja terjadi karena tidak semua penjual online jujur dan profesional (Cooper et al., 2011).

Mui et al. (2002) mengusulkan sebuah sistem reputasi dan mekanisme insentif dalam e-marketplace sebagai cara yang menurutnya efektif untuk membantu pembeli dalam menemukan "recommended seller" atau mitra transaksi terpercaya. Usulan seperti ini sudah diimplementasikan oleh "Agromaret" dengan membuat sistem reputasi berdasarkan akumulasi penilaian pembeli terhadap rating penjual yang pernah melakukan transaksi dalam skor "bintang (1-5)". Namun, sistem reputasi ini belum berjalan dengan baik di "Agromaret" mengingat sistem ini menjadi bagian dari fitur "rekening bersama" yang baru dirilis. Sedangkan "Agribisnispedia" belum memiliki sistem reputasi semacam ini, sehingga konsumen mungkin akan kesulitan dalam menemukan mitra transaksi atau penjual yang jujur. Sistem reputasi secara lazim perlu disediakan untuk mempromosikan kejujuran penjual. Agar dipilih oleh banyak pembeli, penjual harus menjaga reputasi tinggi dengan memberikan produk yang dijanjikan, mengingat bahwa peringkat yang diberikan oleh pembeli dapat mencerminkan perilaku penjual dalam transaksi.

E-marketplace juga harus menyediakan informasi yang relevan untuk membantu konsumen membuat keputusan berdasarkan penilaian manfaat dan risiko sebelum masuk ke dalam transaksi tertentu, terutama untuk "Kecipir" dan "Limakilo" yang menjalankan proses penjualan sendiri. Konsumen sangat tergantung pada informasi yang diberikan karena informasi tersebut bertindak sebagai pengganti "touch and feel". Dari perspektif konsumen, risiko sebagian besar hadir karena barang tidak dapat diperiksa secara fisik sebelum pembayaran penuh dibuat dan adanya masa tunggu sebelum barang dikirim. Akhirnya konsumen harus percaya bahwa penjual akan mengirimkan produk segera setelah pembayaran diterima. Dalam hal ini, penting bagi penjual agar berusaha untuk mencegah terjadinya masalah. Seandainya terjadi masalah, maka harus segera diselesaikan karena konsumen bisa menjadi skeptis pada e-marketplace apabila mereka tidak yakin bahwa setiap masalah yang mereka hadapi dapat diselesaikan dengan cepat (Del Duca et al., 2011).Penjual juga perlu memberikan konsumen kesempatan untuk menyuarakan keluhan mereka (Robertson et al., 2012), karena konsumen memiliki harapan yang tinggi terhadap penjual ketika mereka memutuskan untuk mengeluh (Wilson et al., 2012).

Informasi untuk membantu efisiensi dalam pemilihan produk juga diperlukan oleh konsumen di pasar online. Pembeli online umumnya memerlukan sejumlah pengetahuan yang signifikan dan waktu untuk membuat keputusan membeli yang optimal dari produk yang menjadi pilihannya. Informasi popularitas merupakan solusi untuk meringankan asimetri informasi konsumen. Informasi popularitas bahkan diidentifikasi sebagai salah satu faktor penting yang dibutuhkan untuk meningkatkan kinerja penjualan di pasar online. Contoh informasi popularitas dapat dilihat pada "Kecipir" dengan "Terlaris", "Limakilo" dengan "Produk pilihan", atau "Agribisnispedia" dengan "Hot List". Hanya "Agromaret" satu-satunya yang belum menyediakan informasi semacam ini. Menurut teori pembelajaran observasional (Banerjee, 1992), apabila konsumen kekurangan informasi, mereka akan merujuk pada tindakan pendahulunya yakni 
pembeli sebelumnya yang membuat keputusan untuk membeli suatu produk meskipun tanpa pengetahuan tentang bagaimana pembeli sebelumnya memutuskan untuk membeli. Sementara menurut teori informasi Cascades, mengacu pada pilihan orang lain bisa menjadikan pilihan lebih efisien dan rasional (Li, 2004; Duan et al., 2009).

Perspektif tradisional di kalangan ekonom dalam mempelajari keputusan konsumen membuat asumsi umum bahwa"setiap individu memiliki preferensi yang stabil dan koheren" (Rabin, 1998) dan "setiap orang tahu preferensi mereka" (Freeman, 1993). Asumsi yang tersirat dari perspektif ekonomi ini adalah pelanggan tahu apa yang mereka suka dan mampu membuat pilihan di antara beragam pilihan yang terdefinisi dengan baik sebagai dasar pilihannya. Perspektif ini menganggap bahwa pelanggan memiliki kemampuan komputasi atau keterampilan yang memungkinkan perhitungan opsi yang akan memaksimalkan nilai yang diterima dan pilihan yang sesuai (McFadden, 1999). Dalam hal ini, konsumen akan memilih layanan e-marketplace yang sesuai dengan kebutuhan mereka dan mampu memaksimalkan keberhasilan usaha mereka di lingkungan elektronik.

\section{KESIMPULAN}

Keberhasilan e-marketplace sangat bergantung pada tingkat keterlibatan peserta yang berpartisipasi. Kurangnya kehandalan e-marketplace sering dikritik sebagai salah satu faktor kunci yang mengurangi kepercayaan penjual atau pembeli untuk berpartisipasi. Perusahaan e-marketplace agribisnis tidak cukup untuk hanya menyediakan layanan teknis yang baik seperti transaksi online. Pengguna lebih memperhatikan bagaimana sebuah websitee-marketplace mengelola isinya dan lebih selektif pada layanan pelanggan yang diberikan. Proses pematangan $e$-marketplace diperlukan untuk dapat mempengaruhi persepsi pengguna terhadap kualitas pelayanan teknis, kualitas layanan konten dan kualitas layanan pelanggan. Dengan demikian, ada tekanan pada sisi penyedia untuk meningkatkan kualitas layanannya dan menawarkan sesuatu yang unik di atas standar industri untuk mencapai keunggulan kompetitif atas e-marketplace agribisnis lainnya.

\section{DAFTAR PUSTAKA}

Agarwal, R., and V. Venkatesh. 2002. Assessing a Firm's Web Presence: A Heuristic Evaluation Procedure for the Measurement of Usability. Information Systems Research 13(2002):168-186.

Aladwani, A. M., and P. C. Palvia. 2002. Developing and Validating an Instrument for Measuring User-Perceived Web Quality. Information \& Management 39(2002):467-476.

Arnott, David C. dan Susan Bridgewater. 2002. "Internet, Interaction and Implications for Marketing," Marketing Intelligence and Planning, 20 (2):86-95. 
Bakos, Y.J. 1997. Reducing Buyer Search Costs: Implications for Electronic Marketplaces. Management Science 43 (12), 1-22.

Bakos, Yannis dan Brynjolfsson, Erik. 1999. Bundling Information Goods: pricing, profits, and efficiency. Management Science, 45 (12):1613-1630.

Banerjee, A. 1992. A Simple Model of Herd Behavior. Q. J. Econ. 107 (3), 797817.

Chaffey, D., Mayer R., Johnston, K., dan Elliss-Chadwick, F. 2000. Internet Marketing: Strategy, Implementation, and Practice. England: Prentice Hall.

Cloete, E. and Doens, M. 2008. B2B E-Marketplace Adoption in South African Agriculture, Information Technology for Development, Vol. 14, Issue 3, pp. 184-196.

Cooper, S., Rule, C., Del Duca, L.F. 2011. From Lex Mercatoria to Online Dispute Resolution: Lessons from History in Building Cross-Border Redress Systems. UCCLJ 43, 749-771.

Courtright, C. 2004. Which Lessons Are Learned? Best Practices and World Bank Rural Telecommunications Policy, Information Society, Vol. 20, Issue 5, pp. 345-356.

Del Duca LF, Rule C, Loebl Z. 2011. Facilitating expansion of Cross-Border Ecommerce-Developing A Global Online Dispute Resolution System (lessons derived from existing ODR systems). Work of the United Nations Commission on International Trade Law. Legal Studies Research Paper 252011, Penn State Law, University Park, PA.

Duan, W., Gu, B., Whinston, A.B. 2009. Informational Cascades and Software Adoption on The Internet: an empirical investigation. MIS Q. 33 (1), 23-48.

Eid, Riyad dan Myfanwy Trueman. 2002. "The Internet: New International Marketing Issues," Management Research News, 25 (12):5-67.

Freeman, A. M. 1993. The Measurement of Environmental and Resource Values. Resources for The Future, Washington (DC), 1993.

Fruhling, A. L., and L. A. Digman. 2000. The Impact of Electronic Commerce on Business-Level Strategies. Journal of Electronic Commerce Research 1(2000):13-22.

Gabriele, F.I. 2004. Internet Use and Farmers: How Did the Internet Modify the Buying Habits in the Americas? Brandeis Graduate Journal 2(1): 1-13. 
Goldsmith, R. E., and Bridges, E. 2000. E-tailing vs Retailing: Using Attitudes to Predict Online Buying Behavior. Quarterly Journal of Electronic Commerce, 1, 3, 2000, 245-253.

Jones, J. M., and Vijayasarathy, L. R. 1998. Internet Consumer Catalog Shopping: Findingsfrom an Exploratory Study and Directions for Future Research. Internet Research: Electronic Networking Applications and Policy, 8, 3, 1998, 322-330.

Li, X. 2004. Informational cascades in IT adoption. Commun. ACM 47 (4), 9397.

Manouselis, N., Konstantas, A., Palavitsinis, N., Costopoulou, C., Sideridis, A.B. 2009. A Survey of Greek Agricultural E-Markets, Agricultural Economics Review, Vol. 10, No. 1,pp. 97-112.

McFadden, D. 1999. Rationality for Economists? J Risk Uncertainty, 19, 1-3, 1999, 73-105.

Mui, L., Mohtashemi, M., and Halberstadt. 2002. A. Notions of Reputation in Multi-Agent Systems: a review. In Proceedings of the first International Joint Conference on Automomous Agents and Multiagent Systems (AAMAS), 2002, 280-287.

Nasr, N., Eshghi, A., \& Ganguli, S. 2012. Service Quality in Hybrid Services: A Consumer Value Chain Framework. Journal of Services Research (12:1), 2012,115-130.

Rabin, M. 1998. Psychology and economics. J Econ Lit, 36, 1, 1998, 11-46.

Robertson, N., McQuilken, L., Kandampully, J. 2012. Consumer Complaints and Recovery through Guaranteeing Self-Service Technology. J. Cons. Behaviour 11 (1), 21-30.

Rolfe, J., S. Gregor, and D. Menzies. 2003. Reasons Why Farmers in Australia Adopt the Internet. E-Commerce Research and Applications 2(1): 27-41.

Shu-Chun Ho, Robert J. Kauffman, Ting-Peng Liang. 2007. A Growth Theory Perspective on B2C E-Commerce Growth in Europe: An exploratory study. Electronic Commerce Research and Applications 6 (2007).

Smith, M.D., Bailey, J., Brynjolfsson, E., 2000. Understanding digital markets: review and assessment. In: Brynjolfsson, E., Kahin, B. (Eds.), Understanding the Digital Economy. MIT Press, Cambridge, MA, pp. 99136. 
Smith, A., W. Goe, M. Kenney, and C. Paul. 2004. Computer and Internet Use by Great Plains Farmers. Journal of Agricultural and Resource Economics 29(3): 481-500.

Soekartawi. 2007. Seminar Nasional Aplikasi Teknologi Informasi 2007. Yogyakarta, 16 Juni 2007.

Sullivan, J.R. and Kent A.W. 2001. Consumer Perspectives On Service Quality Of Electronic Commerce Web Sites. Journal of Computer Information Systems (41:3), 2001,8.

Wilson, A., Zeithaml, V.A., Bitner, M.J., Gremler, D.D. 2012. Services Marketing: Integrating Customer Focus across the Firm, 2nd ed. McGraw Hill Education, London, UK.

Zeithaml, V.A., Parasuraman, A. and Malhotra, A. 2002. Service Quality Delivery Through Web Sites: A Critical Review of Extant Knowledge. Journal of the Academy of Marketing Science (30:4), 2002, 362-375.

Website

https://www.apjii.or.id/

https://kominfo.go.id/

http://www.agromaret.com/

http://www.sikumis.com/

https://kecipir.com/

http://agribisnispedia.com/

http://limakilo.id/ 